\title{
Isolation and Characterization of Pathogens Responsible for Urinary Tract Infection in Bangladesh and Determination of their Antibiotic Susceptibility Pattern
}

\author{
Saima Mollick ${ }^{1}$, Tumpa Dasgupta ${ }^{1 *}$, Md. Jabir Hasnain ${ }^{1}$, Mushtaque Ahmed ${ }^{2}$ \\ ${ }^{1}$ Department of Clinical Pharmacy and Pharmacology, University of Dhaka Popular Medical College, Bangladesh. \\ ${ }^{2}$ Popular Medical College, Dhaka, Bangladesh.
}

\begin{tabular}{l} 
ARTICLE INFO \\
\hline Article history: \\
Received on: $24 / 02 / 2016$ \\
Revised on: 19/03/2016 \\
Accepted on: 08/04/2016 \\
Available online: $30 / 04 / 2016$ \\
\hline Key words: \\
Urinary Tract Infection, \\
Sensitivity, E.coli, \\
Staphylococcus aureas, \\
Nitrofurantoin, Vancomycin.
\end{tabular}

\begin{abstract}
The aim and objectives of this study were to determine the etiological pathogens of the Urinary Tract Infection and to determine their antibiotic sensitivity pattern in Bangladesh. This study was carried out on clinically suspected UTI patient in a Private Diagnostic Centre, Bangladesh from May 2015 to November 2015. From total 200 urine samples, pathogens were isolated and identified and their antibiotic susceptibility was observed by standard microbiological procedures. Out of 200 urine samples $124(62 \%)$ patients tested positive for culture. In gram negative bacteria, the most predominant was the E. coli (48.39\%) followed by Klebsiella spp (14.52\%), Pseudomonas spp $(3.23 \%)$ and Acinetobacter spp (3.23\%). In the gram positive bacteria Staphylococcus aureus (13.71\%) and Enterococcus spp (11.29\%) were found. Occasionally Candida spp. (5.65\%) was found. Gramnegative bacteria were more sensitive to Imipenem, Amikacin and Nitrofurantoin. On the otherhand Grampositive bacteria showed their sensitivity to Amoxicillin-clavulinic acid and Linezolid and Vancomycin showed $100 \%$ sensitivity. UTI has become difficult to treat due to appearance of pathogens with increasing resistance to antimicrobial agents. This study showed that pathogens responsible for UTI showed increasing resistance to the commonly prescribed drugs that in turn leaves very few alternative options for the treatment of UTIs.
\end{abstract}

\section{INTRODUCTION}

Urinary Tract Infection (UTI) remains the most common bacterial infection in human population and is also one of the most frequently occurring nosocomial infections (Gastmeir et al., 1998). Its annual global incidence is of almost 250 million (Ronald A R, 2001). Worldwide, about 150 million people are diagnosed with UTI each year, costing the global economy in excess of 6 billion US dollars (Akram et al., 2007). Proliferation of bacteria in the urinary tract is the cause of urinary tract infection. The clinical manifestations of UTI depend on the part of the urinary tract involved, the etiologic organisms, the severity of the infection and the patient's ability to mount an immune response to it (Foxman, 2003). Signs and symptoms may include

\footnotetext{
* Corresponding Author

Tumpa Dasgupta, Department of Clinical Pharmacy and Pharmacology, University of Dhaka.Email: dasgupta@du.ac.bd
}

fever, chills, dysuria, urinary urgency, frequency and cloudy or malodorous urine. The symptoms of a person with urinary tract infections depend on the age and the location. Chronic and acute infection of urinary tract leads to high blood pressure, kidney damage and results in death. Chronic manifestations of the UTIs are acute and chronic pyelonephrits (a disease process resulting from the effect of infection of parenchyma and pelvis of the kidney), cystitis, renal carbuncle, urethritis and prostatitis. UTIs are 14 times more common in females than in males. In males the anatomical length of the urethra $(20 \mathrm{~cm})$ provides a distance barrier that excludes microorganisms from the urinary bladder. Conversely, the short urethra $(5 \mathrm{~cm})$ in females is more readily transverse by microorganisms. In women, the urethra is much shorter and very close to the anus, which is a constant source of fecal bacteria (Zilevièa, 2005). Bacteria are the primary organisms that cause UTI. Gram positive cause $15-20 \%$ and gram negative cause $80-85 \%$. 
Among gram negative Escherichia coli is the most frequent pathogen (Gales, A.C et al., 2002) but in complicated UTI the prevalence of other antibiotic resistance organisms increases such as Kiebsiella, Proteas, seratia, Enterobacter, Pseudomonas. Among gram positives S. saprophyticus, E. faecalis, S. agalactiae, S. pyrogens, S. aureas and B. subtilis are usually prevalent and are resistant to variety of antibiotics (Thomas, 1995). Enterococcus istolates cause 2.3\% of UTI and best known as antibiotic resistant Opportunistic pathogen (Murray, 2000).

UTI is the most frequent nosocomial infection and has been suffering a shift in the etiology and antimicrobial susceptibility, as common as other infection in the last decade. It is important to know the etiology and antibiotic susceptibility of infectious agents to guide the initial empirical treatment (Neto $e t$ al., 2003).

Distribution of urinary pathogens and their susceptibility to antibiotics varies regionally so it becomes necessary to have knowledge of distribution of these pathogens and their susceptibility to antibiotics in a particular setting (Farell et al., 2003). This study is important for clinicians in order to facilitate the effective treatment and management of patient with symptoms of urinary tract infection.

\section{MATERIALS AND METHODS}

This study was planned in one of the renowned diagnostic center, in Dhaka with objectives to find out the etiological pathogens of the UTI and to determine the antibiotic sensitivity pattern of pathogens isolated. The study duration spanned from May 2015 to November 2015. Study population consisted of the clinically suspected UTI patients who visited the outpatient department. Total 200 midstream samples were collected during this study period. For collection of urine samples patients were advised to collect a clean catch midstream urine specimen in a sterile, wide mouthed leak proof container supplied by the laboratory and bring to the laboratory as early as possible. Isolation and identification of bacterial pathogens was done by microscopy and culture and drug sensitivity methods.

Microscopic Examination: Five $\mathrm{ml}$ of urine samples were poured into a clean and dry $15 \mathrm{ml}$ centrifuge tubes and centrifuged at 3000 RPM for 5 minutes. The supernatant fluid was discarded and one drop of sediment was transferred to a clean labeled glass slide, covered with a clean cover slip and then examined under a light microscope using 10X and 40X magnifications. On the basis of findings of pus cells/ HPF, urine samples were placed into cultural examination (Chowdhury, 1998). Then Gram's stain was performed.

\section{Culture procedure}

Sterile urine samples were shaken well in their sterile containers for even distribution of organisms. A calibrated wire loop with internal diameter of $3.26 \mathrm{~mm}$ that hold $0.004 \mathrm{ml}$ of urine were inoculated into Blood agar, MacConkey agar and UTI agar.
The inoculums were spread with the wire loop on the media plate. They were incubated aerobically at $37^{\circ} \mathrm{C}$ for 24 hours (Collee et al., 1996)

After completion of incubation, the inoculated culture plates will be observed for presence of any bacterial growth. If growth occurs, colony count will be done to calculate the number of colony forming unit per $\mathrm{ml}$ of urine. A significant bacterial count was taken as any count equal to or in excess of 100,000 CFU $/ \mathrm{ml}$. A less than $100 \mathrm{CFU} / \mathrm{ml}$ was interpreted as negative. Bacterial isolates were identified generally using conventional biochemical tests.

\section{Antibiotic susceptibility testing}

Susceptibility pattern was done by disk diffusion method. All the isolated organisms were put into appropriate media for antibiotic susceptibility test by Kirby-Bauer disc diffusion technique. Disc diffusion tests were performed and interpreted according to the recommendations of the Clinical and Laboratory Standards Institute (CLSI, 2007). All tests were performed on Muller-Hinton agar plates ( $\mathrm{pH}$ 7.2-7.4). The surface was lightly and uniformly inoculated by sterile cotton swab stick. Prior to inoculation, the swab stick was dipped into bacterial suspension having visually equivalent turbidity to $0.5 \mathrm{McFarland}$ standards. The swab stick was then took out and squeezed on the wall of the test tube to discard extra suspension. Inoculated plates were incubated at $37^{\circ} \mathrm{C}$ for 24 hours.

\section{RESULT \& DISCUSSION}

UTI ranked among the most common infection in developing countries. In this study a total of 124(62\%) out of 200 patients had UTI. This indicates that urine culture and antimicrobial susceptibility is essential for a definitive diagnosis of UTI. Female predominance was observed in this study. Our study showed $76.61 \%$ female and $26.39 \%$ male were affected by UTI which was almost similar to the study done by Gupta et al. (2002) where female and male were $82.72 \%$ and $18.93 \%$ respectively. There was a predominance of young and middle aged females. Our results indicate that the incidence in adult females was about 9 times higher than males of similar age whereas in older age groups of 60 years and above, male and female were equally affected.

The organism mostly isolated from UTI patient was E. coli 60 (48\%) followed by Klebsiella spp 18 (14.52\%), Pseudomonas spp 4 (3.23\%), Acinetobacter spp 4 (3.23\%), Staphylococcus aureus 17 (13.71\%), Enterococcus spp 14 (13.71\%) and Candida spp 7 (5.65\%), (Figure 1). The reason of highest rate of isolation of E. coli causing UTI is due to the fact that most of the bacterial organisms causing UTI originate from the fecal flora and among these facultative anaerobes, $E$ coli constitutes the major portion superimposed by various virulence factors that facilitate the ascent of bacteria from fecal flora, introitus or periurethral area, up the urethra into the bladder and less frequently allow the organisms to reach the kidneys to induce symptomatic inflammation (Sobel et al.,1995). The dissimilarities of the rate of 
isolation and isolated bacterial species between the present study and various other studies may be due to the passage of time, geographical variation, difference among sexes, various personal, educational and overall socioeconomic status, availability of medical facilities, method of collection of urine samples etc. Although the spectrum of pathological bacteria isolated from the urine of patients across the globe remained largely unchanged over the past few decades there have been dramatic changes in the resistance pattern and sensitivity profile in most countries (Kadri et al., 2004).

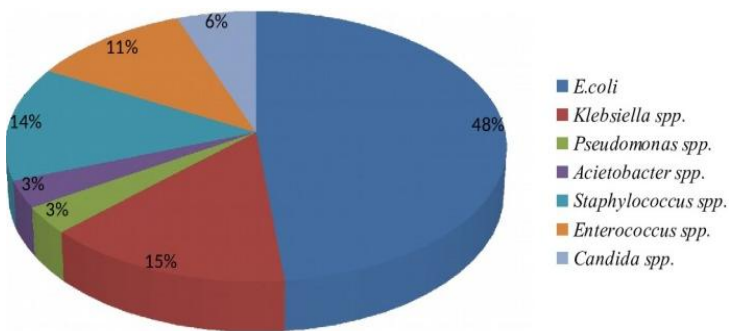

Fig. 1: distribution of positive isolates identified from urine samples.

Not every antimicrobial agent is equally effective against both gram-positive and gram-negative bacteria. In our study antibiogram (Table 1) of urinary pathogens isolated reveals that $E$. coli were less sensitive to commonly used drugs like Cephradine (25\%), Ciprofloxacin (25\%), Levofloxacin (28.34\%), ceftriaxone $(33.33 \%)$, Tetracyclin (33.33\%), Cefixim (35\%), Doxycycline (36.67). Sensitivity to Cotrimoxazole (46.66\%) Ceftazidime (61.66), Cefipime (65\%), Gentamicin $(71.66 \%)$, were moderate.

In this study Imipenem (98.33\%) was the most sensitive against $E$. coli that is in agreement with the same findings by Sharmin (2005). E.coli was shown sensitivity towards Meropenem (98.33\%) and Amikacin (90\%).

Another researcher from Bangladesh picked that $(78.89 \%)$ E. coli were resistant to Cotrimoxazole $(72.22 \%)$, Tetracycline $(71.11 \%)$. While minimum resistance $(27.78 \%)$ were shown towards Ceftazidime followed by Ceftriaxone (35.56\%) and Gentamicin (43.33\%) (Chaudhury, 1998). In a study in Netherlands, the level of resistance towards Cotrimoxazole was $92.8 \%$ that was higher than our study and towards Ciprofloxacin and Nitrofurantoin $38.8 \%$ and $7.7 \%$ that was lower than our study (Sham et al., 2000). S. aureus and Enterococcus spp were the two Gram positive isolates and made up $25 \%$ of all isolates. Most of the $S$. aureus were proved to be resistant to one or more antibiotics used in this study. Among antibiotics the most resistance was proved to Cephalosporins. Resistance was shown to Imipenem $(88.24 \%)$ and Meropenem (88.24\%). S. aureus were moderately sensitive to Gentamicin (64.71\%). The most susceptible antimicrobial agent for $S$. aureus were Nitrofurantoin $(94.12 \%)$ and Linezolid (94.12\%). Cotrimoxazole (70.59\%) and Amikacin (70.59\%) also had good sensitivity result. Amoxicillin/clavulanic acid combination is fairly active against organism sensitive to Amoxicillin. However in this study the Staphylcoccus aureas found in this study showed moderate sensitivity $(52.94 \%)$ and
Enterococcus spp. were found to be $100 \%$ sensitive to this combination. None of the Gram positive isolate showed resistance against Vancomycin.

Enterococcus spp. found in this study showed moderate sensitivity to Ampicillin. Doxycycline, Tetracycline and better against Nitrofurantoin $(85.71 \%)$. Enterococcus spp. have naturally occurring, or intrinsic, resistance to: Cephalosporins, Trimethoprim-sulfamethoxazol, Low or therapeutic concentrations of aminoglycosides.

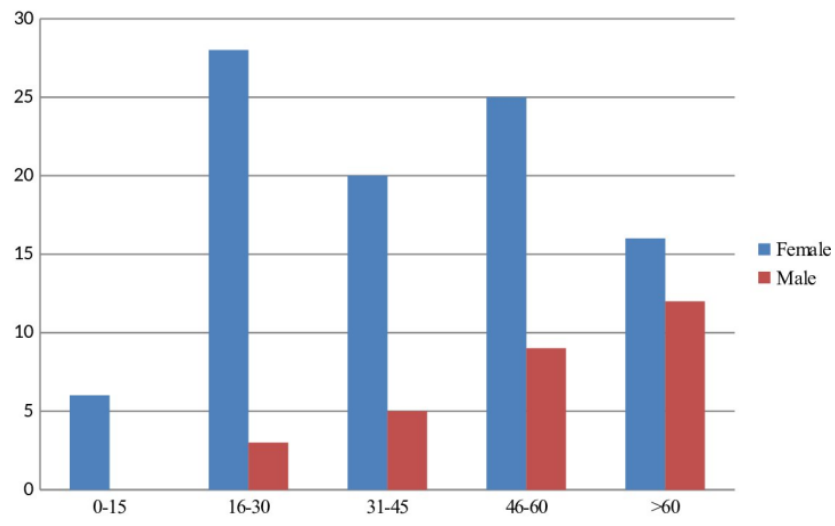

Fig. 2: distribution of patients with UTI by different age groups \& gender.

The empirical use of commonly used antibiotics led the drug resistant phenomenon. Cotrimoxazole being a commonly used drug to treat UTI once, the use of it has been reduced by many folds due to its resistance pattern. Cotrimoxazole was found to be ineffective for UTI in the present study as all the uropathogens showed high degree of resistance to it. The very high rate of Ciprofloxacin resistance among both Gram negative and Gram positive organisms observed in our study can possibly be attributed to Ciprofloxacin being a commonly prescribed drug in our tertiary care hospital and thus warrants special precaution. Majority of the UTI patients in our country receive Cephalosoprins, Aminoglycosides, Fluoroquinolone or a combination of these drugs as empirical therapy or as definitive treatment. Though Nitrofurantoin is a narrow spectrum antibiotic, is still now an effective drug treating UTI. Since good in-vitro activity was shown by Nitrofurantoin it may be considered as first line oral therapy for ambulatory patients. Drugs, which retained usefulness for Gram-negative isolates, were Imipenem, Nitrofurantoin and Gentamicin and for Gram-positive isolates the drugs were Linezolid, Amikacin and Vancomycin.

Sensitivity pattern is changing day by day and it varies even in the same city, country to country. The emergence and spread of resistance can be reduced through appropriate or careful use of antimicrobial drugs and increasing awareness among the population to the hazards of inappropriate antimicrobial use through public health education campaign. Sensitivity tests should be routinely performed in all UTI cases. Appropriate antibiotics need to be prescribed based on the antibiotic susceptibility test which will be narrow spectrum, effective and less expensive with least side effects. 
Table. 1: Antibiotic sensitivity Pattern of UTI Isolates.

\begin{tabular}{|c|c|c|c|c|c|c|c|}
\hline Antibiotic & Sensitivity & $\begin{array}{l}\text { E.coli } \\
\mathrm{N}(\%)\end{array}$ & $\begin{array}{c}\text { Klebsiella } \\
\text { spp. } \\
\mathrm{N}(\%)\end{array}$ & $\begin{array}{c}\text { Pseudo. } \\
\text { spp. } \\
\text { N }(\%)\end{array}$ & $\begin{array}{c}\text { Acineto. } \\
\text { spp. } \\
\mathrm{N}(\%)\end{array}$ & $\begin{array}{c}\text { S. aureus } \\
\mathrm{N}(\%)\end{array}$ & $\begin{array}{c}\text { Entero. } \\
\text { spp. } \\
\mathrm{N}(\%)\end{array}$ \\
\hline Ampicillin & $\begin{array}{l}\mathrm{S} \\
\mathrm{R}\end{array}$ & N/D & N/D & $\mathrm{N} / \mathrm{D}$ & $\mathrm{N} / \mathrm{D}$ & N/D & $\begin{array}{l}9(64.29) \\
5(35.71)\end{array}$ \\
\hline Cephradine & $\begin{array}{l}\mathrm{S} \\
\mathrm{R}\end{array}$ & $\begin{array}{l}15(25) \\
45(75)\end{array}$ & $\begin{array}{l}4(22.23) \\
14(77.77)\end{array}$ & $\mathrm{N} / \mathrm{D}$ & $\begin{array}{l}1(25) \\
3(75)\end{array}$ & $\begin{array}{l}2(11.76) \\
15(88.24)\end{array}$ & N/D \\
\hline Ceftriaxone & $\begin{array}{l}\mathrm{S} \\
\mathrm{R}\end{array}$ & $\begin{array}{l}20(33.33) \\
40(66.66)\end{array}$ & $\begin{array}{l}8(44.44) \\
10(55.56)\end{array}$ & N/D & $\begin{array}{l}1(25) \\
3(75)\end{array}$ & $\begin{array}{l}2(11.76) \\
15(88.24) \\
\end{array}$ & N/D \\
\hline Cefixime & $\begin{array}{l}\mathrm{S} \\
\mathrm{R}\end{array}$ & $\begin{array}{l}21(35) \\
39(65)\end{array}$ & $\begin{array}{l}8(44.44) \\
10(55.56)\end{array}$ & $\begin{array}{l}2(50) \\
2(50)\end{array}$ & $\begin{array}{l}1(25) \\
3(75)\end{array}$ & $\begin{array}{l}2(11.76) \\
15(88.24)\end{array}$ & N/D \\
\hline Ceftazidime & $\begin{array}{l}\mathrm{S} \\
\mathrm{R}\end{array}$ & $\begin{array}{l}37(61.66) \\
23(38.33) \\
\end{array}$ & $\begin{array}{l}10(55.56) \\
8(44.44)\end{array}$ & $\begin{array}{l}2(50) \\
2(50) \\
\end{array}$ & $\begin{array}{l}2(50) \\
2(50) \\
\end{array}$ & $\begin{array}{l}2(11.76) \\
15(88.24) \\
\end{array}$ & N/D \\
\hline Cefepime & $\begin{array}{l}\mathrm{S} \\
\mathrm{R}\end{array}$ & $\begin{array}{l}39(65) \\
21(35)\end{array}$ & $\begin{array}{l}10(55.56) \\
8(44.44)\end{array}$ & $\begin{array}{l}2(50) \\
2(50)\end{array}$ & $\begin{array}{l}2(50) \\
2(50)\end{array}$ & $\begin{array}{l}2(11.76) \\
15(88.24)\end{array}$ & $\mathrm{N} / \mathrm{D}$ \\
\hline Imipenem & $\begin{array}{l}\mathrm{S} \\
\mathrm{R}\end{array}$ & $\begin{array}{l}59(98.33) \\
1(1.66)\end{array}$ & $\begin{array}{l}18(100) \\
0(00\end{array}$ & $\begin{array}{l}4(100) \\
0(0)\end{array}$ & $\begin{array}{l}3(75) \\
1(25)\end{array}$ & $\begin{array}{l}2(11.76) \\
15(88.24)\end{array}$ & N/D \\
\hline Meropenem & $\begin{array}{l}\mathrm{S} \\
\mathrm{R}\end{array}$ & $\begin{array}{l}59(98.33) \\
1(1.66)\end{array}$ & $\begin{array}{l}17(94.44) \\
1(5.56)\end{array}$ & $\begin{array}{l}4(100) \\
0(0)\end{array}$ & $\begin{array}{l}3(75) \\
1(25)\end{array}$ & $\begin{array}{l}2(11.76) \\
15(88.24)\end{array}$ & N/D \\
\hline Cotrimoxazole & $\begin{array}{l}\mathrm{S} \\
\mathrm{R}\end{array}$ & $\begin{array}{l}28(46.66) \\
32(53.33)\end{array}$ & $\begin{array}{l}8(44.44) \\
10(55.56)\end{array}$ & N/D & $\begin{array}{l}1(25) \\
3(75)\end{array}$ & $\begin{array}{l}12(70.59) \\
5(29.41)\end{array}$ & $\mathrm{N} / \mathrm{D}$ \\
\hline Linezolid & $\begin{array}{l}\mathrm{S} \\
\mathrm{R}\end{array}$ & $\mathrm{N} / \mathrm{D}$ & N/D & N/D & N/D & $\begin{array}{l}16(94.12) \\
1(5.88)\end{array}$ & $\begin{array}{l}12(85.71) \\
2914.29)\end{array}$ \\
\hline Gentamicin & $\begin{array}{l}\mathrm{S} \\
\mathrm{R}\end{array}$ & $\begin{array}{l}43(71.66) \\
17(28.34)\end{array}$ & $\begin{array}{l}14(77.77) \\
4(22.23)\end{array}$ & $\begin{array}{l}2(50) \\
2(50)\end{array}$ & $\begin{array}{l}3(75) \\
1(25) \\
\end{array}$ & $\begin{array}{l}11(64.71) \\
6(35.29)\end{array}$ & $\mathrm{N} / \mathrm{D}$ \\
\hline Ciprofloxacin & $\begin{array}{l}\mathrm{S} \\
\mathrm{R}\end{array}$ & $\begin{array}{l}15(25) \\
45(75)\end{array}$ & $\begin{array}{l}12(66.67) \\
6(33.33) \\
\end{array}$ & $\begin{array}{l}2(50) \\
2(50)\end{array}$ & $\begin{array}{l}2(50) \\
2(50)\end{array}$ & $\mathrm{N} / \mathrm{D}$ & $\begin{array}{l}7(50) \\
7(50) \\
\end{array}$ \\
\hline Levofloxacin & $\begin{array}{l}\mathrm{S} \\
\mathrm{R}\end{array}$ & $\begin{array}{l}17(28.34) \\
43(71.66)\end{array}$ & $\begin{array}{l}12(66.67) \\
6(33.33)\end{array}$ & $\begin{array}{l}2(50) \\
2(50)\end{array}$ & $\begin{array}{l}2(50) \\
2(50)\end{array}$ & N/D & $\begin{array}{l}7(50) \\
7(50) \\
\end{array}$ \\
\hline Doxycycline & $\begin{array}{l}\mathrm{S} \\
\mathrm{R}\end{array}$ & $\begin{array}{l}22(36.67) \\
38(63.33)\end{array}$ & $\begin{array}{l}7(38.89) \\
11(61.11)\end{array}$ & N/D & $\begin{array}{l}2(50) \\
2(50)\end{array}$ & $\begin{array}{l}7(44.18) \\
10(58.82)\end{array}$ & $\begin{array}{l}9(64.25) \\
5(35.71) \\
\end{array}$ \\
\hline Tetracycline & $\begin{array}{l}\mathrm{S} \\
\mathrm{R}\end{array}$ & $\begin{array}{l}20(33.33) \\
40(66.67)\end{array}$ & $\begin{array}{l}7(38.89) \\
11(61.11)\end{array}$ & N/D & $\begin{array}{l}2(50) \\
2(50)\end{array}$ & $\begin{array}{l}6(35.29) \\
11(64.71)\end{array}$ & $\begin{array}{l}9(64.25) \\
5(35.71)\end{array}$ \\
\hline Nitrofurantoin & $\begin{array}{l}\mathrm{S} \\
\mathrm{R}\end{array}$ & $\begin{array}{l}49(81.67) \\
11(18.33) \\
\end{array}$ & $\begin{array}{l}13(72.22) \\
5(27.78) \\
\end{array}$ & $\mathrm{N} / \mathrm{D}$ & $\begin{array}{l}3(75) \\
1(25) \\
\end{array}$ & $\begin{array}{l}16(94.12) \\
1(5.88) \\
\end{array}$ & $\begin{array}{l}12(85.71) \\
2(14.29)\end{array}$ \\
\hline Amikacin & $\begin{array}{l}\mathrm{S} \\
\mathrm{R} \\
\end{array}$ & $\begin{array}{l}54(90) \\
6(10) \\
\end{array}$ & $\begin{array}{l}16(88.89) \\
2(11.11) \\
\end{array}$ & $\begin{array}{l}2(50) \\
2(50) \\
\end{array}$ & N/D & $\begin{array}{l}12(70.59) \\
5(29.41) \\
\end{array}$ & N/D \\
\hline Aztreonam & $\begin{array}{l}\mathrm{S} \\
\mathrm{R}\end{array}$ & $\begin{array}{l}29(48.33) \\
31(51.67) \\
\end{array}$ & $\begin{array}{l}7(38.89) \\
11(61.11) \\
\end{array}$ & $\begin{array}{l}3(75) \\
1(25) \\
\end{array}$ & $\begin{array}{l}3(75) \\
1(25) \\
\end{array}$ & N/D & N/D \\
\hline $\begin{array}{l}\text { Tazobactam + } \\
\text { Pipercilin }\end{array}$ & $\begin{array}{l}\mathrm{S} \\
\mathrm{R}\end{array}$ & N/D & N/D & $\begin{array}{l}3(75) \\
1(25) \\
\end{array}$ & $\mathrm{N} / \mathrm{D}$ & N/D & $\begin{array}{l}14(100) \\
0(0)\end{array}$ \\
\hline Amoxicillin +Clavulanic Acid & $\begin{array}{l}\mathrm{S} \\
\mathrm{R}\end{array}$ & $\mathrm{N} / \mathrm{D}$ & $\mathrm{N} / \mathrm{D}$ & N/D & $\mathrm{N} / \mathrm{D}$ & $\begin{array}{l}12(70.59) \\
5(29.41)\end{array}$ & $\begin{array}{l}14(100) \\
0(0)\end{array}$ \\
\hline Vancomycin & $\begin{array}{l}\mathrm{S} \\
\mathrm{R}\end{array}$ & $\mathrm{N} / \mathrm{D}$ & $\mathrm{N} / \mathrm{D}$ & N/D & $\mathrm{N} / \mathrm{D}$ & $\begin{array}{l}17(100) \\
0(0)\end{array}$ & $\begin{array}{l}14(100) \\
0(0)\end{array}$ \\
\hline $\begin{array}{l}\text { N.B: } \text { Pseudo.spp. }=\text { Pseudomo } \\
\text { Acineto.spp }=\text { Acinetobac } \\
\text { Entero.spp }=\text { Enterococc } \\
\text { N/D }=\text { Not Done }\end{array}$ & $\begin{array}{l}s p p \\
s p p \\
p p\end{array}$ & & & & & & \\
\hline
\end{tabular}

\section{CONCLUSION}

According to findings, Gram-negative bacteria were mainly responsible for urinary tract infections and the most common isolated bacteria from urinary tract infections were $E$. coli. In this study, the most effective antimicrobial agents were Imipenem, Amikacin and Nitrofurantoin against Gram-negative bacteria. On the otherhand, the most effective antibiotics against Gram-positive bacteria were Amoxicillin-clavulinic acid and Linezolid and Vancomycin showed $100 \%$ sensitivity.UTI, which have traditionally been readily treatable, are now becoming therapeutic challenges. This study will guide physicians in making right choice of drugs while treating patients thus ensuring effective and quick treatment of the infection and preventing antibiotic resistance.

\section{ACKNOWLEDGEMENT}

The author is thankful to the Department of Clinical Pharmacy and Pharmacology and Faculty of Pharmacy of University of Dhaka for their support to conduct this research project. And also acknowledge the contribution of Popular Diagnostic Center, Dhaka, Bangladesh for giving all the facilities to conduct this research work. 


\section{REFERENCES}

Akram, M., Shahid, M. and Khan, A. Etiology and antibiotic resistance patterns of community acquired Urinary tract infection in JNMC Hospital Aligarh, India., Ann Clin Microbiol Antimicrob, 2007; 6,

Collee, J. G., Duguid, J. P., Fraser, A. G. and Marmion, B. P. 1996. Laboratory strategies in the diagnosis of infectious syndromes. in Practical Medical Microbiology, eds Collee, J. G., Barrie, M. P., Fraser, A.G. and Simons, A. ,14th ed. Churchill Livingstone, New York, 53-93.

Chowdhury, A. 1998. Urinary tract infection in pregnancy: a bacteriological study, M phil (Microbiology) Thesis, Bangabandhu Sheikh Mujib Medical University, Bangladesh, 2-101.

Clinical and Laboratory Standards Institute (CLSI). 2007. Interpretive chart of zone sizes Performance Standards for Antimicrobial Susceptibility Testing, Seventeeth Informat- ional Supplement. USA, 27 (1), 32-52.

Farrell DJ, Morrissey I, De Rubeis D et al. A UK multicentre study of the antimicrobial susceptibility of bacterial pathogens causing urinary tract infection. J Infect, 2003; 46(2):94-100

Foxman, B. Epidemiology of urinary tract infections: Incidence, morbidity and economic costs. Dis. Mon., 2003; 49: 53-70

Gales, A.C., H.S. Sader and R.N. Jones, Urinary tract infection trends in Latin American Hospitals. Diagn. Microbiol. Infect. Dis., 2002; 44: 289-299.

Gastmeir P, Kampf G, Wischnewski N, Hauer T, Schulgen G, et al. Prevalence of nosocomial infections in representative German hospitals. J. Hosp. Infect, 1998; 38: 37-49.

Gupta, V., Yadab, A. and Joshi, R. M. Antibiotic resistance pattern in Uropathogens., Indian Journal of Medical Microbiology, 2002; $20(2), 96-98$

Kadri, S. M., Gash, B. and Rukhsana, A. Antibiotic Sensitivity and Resistance Profile of the Micro-organisms Responsible for Urinary Tract Infection Observed in Kashmir, India., Indian Journal for the Practising Doctor, 2004; 1(1), 79-84.
Murray, B.E. Vancomycin-resistant enterococcal infections. The New England J. Medicine, 2000; 342: 710-721.

Neto, J. A. D., Martins,A. C. P., Silva, L. D. M., Tiraboschi, R. B., Domingos, L. A., Suaid, H. J., Tucci, S. and Cologna, A. J. Prevalence and bacterial susceptibility of hospital acquired urinary tract infection., Acta Cirurgica Brasileira, 2003; 18 (suppl.5), 23-25.

Ronald AR, Nicolle LE, Stamm E, et al. Urinary tract infection in adults: research priorities and strategies. Int J Antimicrob Agents. 2001; 17:343-8.

Sobel, J. D. and Kaye D. 1995. Urinary tract infections. in Principles and Practice of Infectious Diseases, eds. Mandell, G. L., Bennett J. E. and Dolin, R. 4th ed. Churchill Livingstone, New York, 662 690.

Sharmin, S. 2005. Use of chromogenic media for detection of uropathogen, M phil (Microbiology) Thesis, Bangabandhu Sheikh Mujib Medical University, Bangladesh.

Sahm, D. F., Thornsberry, C., Mayfield, D. C. Multidrug resistant urinarytract isolates of E.coli: prevalence and patients demographics in the United States in 2000. Antimicrob Agents Chemother, 2000; 45, 1402-1406.

Thomas, J.G. 1995. Urinary Tract Infections. In: Diagnostic Microbiology. (Eds Mahon, C.R. and G. Manuselis). pp: 950-969

Zilevièa, A. Hospital-acquired and Community- acquired Uropathogens, Modelling of Infection. Bioautomation, 2005; 3, 63 . 67.

\section{How to cite this article:}

Mollick S, Dasgupta T, Hasnain MJ, Ahmed M. Isolation and Characterization of Pathogens Responsible for Urinary Tract Infection in Bangladesh and Determination of their Antibiotic Susceptibility Pattern. J App Pharm Sci, 2016; 6 (04): 072-076. 